\title{
The relationship between science process skills and student attitude toward physics in senior secondary school in Aliero metropolis
}

\author{
Kamba A. H., Giwa A. A., Libata I. A. and Wakkala G. T. \\ Department of Science Education, Kebbi State University of Science and Technology, Aliero, Kebbi State, Nigeria.
}

Accepted 26 June, 2018

\begin{abstract}
This study investigated the relationship between science process skills and student attitude toward physics in senior secondary school in Aliero metropolis. The study adopted a descriptive survey design and data were largely descriptive by nature. Two set of questionnaires namely; Science Process Skills Test (SPST) and Attitudes toward Physics Questionnaire (ATPQ) was used for Data collection constructed by the researcher. These were administered to a sample of 203 students selected from three secondary schools in Aliero metropolis out of which 165 filled questionnaires were returned to the researcher. The major findings of the study indicate that the students' knowledge of science process skills is poor, the student's attitudes towards physics are good and there is a significant positive relationship between students' knowledge of science process skills and their attitudes towards physics. Based on the findings, it was concluded that students should be exposed to science process skills for the betterment of their future life and the society as well, the level of students' attitudes toward physics is good but not enough, as such, positive attitudes of students should be improved so that they can be able to think, to reflect and to associate with ideas related to physics.
\end{abstract}

Keywords: Relationship, science process skills, student attitude, physics.

*Corresponding author. E-mail: aliyuhassankamba@gmail.com. Tel: 08038046206.

\section{INTRODUCTION}

Science process skills are defined as tools that acquires information about the world and on the other hand is also defined as problem identifier, formulation of the hypothesis about the problem, making valid prediction, identifying and defining of variables, designing and experiment to test the hypothesis. Science process skills are categorized into two, these are basic process skills and Integrated process skills. Some of the basic process skills are observing, classifying, communicating, measuring, using space/time relationships, using figure, inferring and predicting; while integrated process skills are identifying the problem, interpreting data, defining operationally reading/constructing graphs and experimenting (Padilla, 1990).

One of the most important goals of science education is to teach students how to get involved in inquiry. In other words, students should integrate skills, knowledge, and attitudes to develop a better understanding of scientific concepts. Teachers must therefore focus on teaching science skills such as facts, concept and theories, to encourage students through scientific investigation. Physics is a fulcrum subject among the sciences that requires special attention. Advancements in technologies, information and communication, medical, environmental, crime control and security are feats through the knowledge of physics. Physics is perceived as a difficult course for student from secondary school to university and also for adults in graduate education. It is well known that both high school and college students find physics difficult. The measurement of student's attitudes towards physics should take into account their attitude towards learning environment. Research has shown that the attitude towards science change with exposure to science, but the direction of change may be related to the 
quality of that exposure, the learning environment and teaching method. Attitudes are general dispositions that stand behind people's evaluations and emotional feelings. Attitudes arise from human needs and are expressions of people's intellectual processes (Wheeler et al., 1974). Attitudes toward science refer to a general, enduring, positive or negative disposition about science (Thomas et al., 1985). An attitude consists of three aspects: affective, cognitive and behavioral (Arnson et al., 1994). An affective component consists of an individual's dispositions about the attitude object. A cognitive component is the individual's beliefs or knowledge about the attitude object, and the behavioral component is the individual's predisposition to act toward the attitude object in a particular way (Gall et al., 2003).

The term attitude is defined the frame work of Social Psychology as a subject or mental preparation for action. This definition incorporates the outward and visible postures and human beliefs. Attitude determines what each individual will see, hear, think and do.

\section{Statement of the problem}

Lack of science process skills in physics is a known fact and of great concern to physics student. Many students need basic science process skills that encourage them to study science subject such as physics, lack of this skills such as classifying, communicating, interpreting, measuring, these entire problem hindered student in studying science subject in our secondary schools. Therefore, physics seems to be the subject that many student hates and are likely to avoid. It is viewed as comprising of numbers and manipulation perceived as less applicable in real life situation. As such most students from SSI to SSIII both male and female attend physics classroom with hesitation. So many factors could be said to have contributed to this problem among which is the student's attitudes. Further, poor performance has been witness in physics as more than $60 \%$ of students that often sit for the SSCE examination every year do fail the course physics subject due lack of science process skills.

\section{Purpose of the study}

The main purpose of this study is to find out the relationship between science process skills and student attitude toward physics in senior secondary school in Aliero metropolis, Kebbi State, Nigeria.

\section{Objectives of the study}

1. Determination of the students' science process skills. 2. Attitude of male and female students toward physics subject in secondary school in Aliero metropolis to be determined.

3. To determine the relationship between the levels of students' knowledge of science process skills and their level of attitude toward physics.

\section{Research questions}

1. What are the student science process skills?

2. What are the levels of Male and Female student attitude toward physics?

3. What are the relationships between the science process skills and students attitude toward physics?

\section{Research hypothesis}

There is positive relationship between the levels of students' knowledge of science process skills and their level of attitude toward physics

\section{Significance of the study}

This study will enable the researcher to have first-hand knowledge on science process skills that will enable individuals to develop a basic skill in terms of communication, observation, interpretation, prediction, and making valid conclusion. This study will therefore shed more light on how a student's attitude affects the learning of physics. And also this research work will help the administrators of the school in which the research was carried out to realize the problems (inadequate science laboratory equipment) of learning physics in their school, and how they can be tackled. It will make an individual realize the importance of physics in their daily lives.

\section{METHODOLOGY}

\section{Research design}

The study adopted descriptive correlational design. Descriptive correlational design was chosen because the researcher collects data from large number of respondents in other to determine the relationship between the science process skills and the level of student attitudes towards physics. The target population for the study included all SS III students from three secondary schools in Aliero Local Government, including Government Science Secondary School (boys), Government Girls Science Secondary School and University Staff Secondary School. According to the Schools' Registers (2017), there are four hundred and fifteen (415) SS III students in the selected schools. 


\section{Sample size and sampling strategy}

From the population of 415 students, the sample size of 203 students was drawn using the Slovene's formula as follows:

$$
\mathrm{n}=\left(\mathrm{N} / 1+\mathrm{Ne}^{2}\right)
$$

Where: $\mathrm{n}$ - sample size

$\mathrm{N}$ - Population

e - margin of error (0.05)

$$
\mathrm{n}=\frac{\mathrm{N}}{\left(1+N e^{2}\right)}
$$

$\mathrm{n}=415 \div\left[1+\left(415 \times 0.05^{2}\right)\right]$

$\mathrm{n}=2547 \div[1+(415 \times 0.0025)]$

$\mathrm{n}=415 \div[1+1.04]$

$\mathrm{n}=415 \div 2.04$

$\mathrm{n}=203$

Therefore, the sample size $(n)=\underline{203}$ respondents

Systematic random sampling was used. In this strategy, each respondent was selected after a given equal interval which is called a systematic random number and it is given by the ratio of the population size to the sample size $(N / n)$, that is, $415 / 203=2$. This means that after every 2 respondents, 1 respondent was selected. This was used because the researcher could access the list of all students.

\section{Research instruments}

The instruments used to collect data in this study were two set of questionnaires: Science Process Skills Test (SPST) adopted from the work of Zeidan and Jayosi (2015); and Attitudes Toward Physics Questionnaire (ATPQ) constructed by the researcher. Each of the instruments consists of two sections, A and B. Questions about the demographic characteristics of respondents were contained in section A, Section $B$ in the first instrument contains closed-ended questions about the students' knowledge of science process skills while section in the second instrument contains close-ended questions about attitudes of respondents towards physics. Questions in sections B of the first instrument were prepared in objective form, with options lettered $A$ to $D$ from which the respondents chose the most appropriate option. Questions in sections B of the second instrument were prepared based on a four-point Likert scale, ranging from " 1 = Strongly Disagree, 2 = Disagree, 3 = Agree, 4 = Strongly".

\section{Validity}

Check by experts for language, clarity, relevance, and comprehensiveness of the content. The items were rated as follows: 4 - Very relevant, 3 - Quite relevant, 2 Somewhat relevant and 1 - Not relevant.

The researcher then put the items in 2 groups, with categories 1 and 2 in one group and the other 3 and 4 in the other group. The researcher then calculated the Content Validity Index $(\mathrm{CVI})$ using the formula below:

Items rated as very relevant and relevant ( 3 and 4 )

$$
\mathrm{CVI}=\mathrm{T}_{\text {Total number of items }}
$$

For the instrument to be valid, the CVI had to be within the accepted statistical range of 0.7 to 1 . Computed CVI for the first instrument was found to be 0.7 , and for the second instrument, computed CVI was found to be 0.76 .

\section{Reliability}

In order to establish the reliability of the instruments, the researcher conducted a test study using fifteen people who were not part of the study sample. Using the results of the study, the reliability of the instruments was computed using Cronbach's Alpha Coefficient to prove the reliability of instruments with the coefficients within the accepted statistical range of 0.7 to 1 . And the study got a coefficient of 0.69 and 0.72 for the first and second instruments respectively hence the instruments were reliable.

\section{Data analysis}

Using SPSS version 16.0, the researcher used tables (frequency counts and percentages) to analyze the profile of respondents, mean to analyze the respondents' level of knowledge of science process skills as well as the level of their attitudes towards physics and Pearson's $r$ to analyze the data with respect to the relationship between respondents' level of knowledge of science process skills and level of their attitudes towards physics.

The following formula was used to calculate the mean range:

\section{Highest score - Lowest score \\ Mean range $=\frac{\text { Highest score }}{\text { Highe }}$}

In this study, the researcher used a 4 - point Likert scale so,

Highest score $=4$

Lowest score $=1$

This implies that,

range $=\frac{4-1}{4}$ 
range $=\frac{3}{4}$

range $=0.75$

\section{RESULTS AND DISCUSSION}

The findings are presented in accordance with the research questions after presenting the demographic information of respondents.

\section{Demographic characteristics of the respondents}

The data on demographic characteristics of the respondents of the study in Table 1 show that majority of the respondents are from public schools $(87.88 \%)$, boarding school students $(75.76 \%)$, male $(58.79 \%), 18$ years $(55.15 \%)$.

\section{What is the level of students' knowledge of science process skills?}

As shown in Table 2, the independent variables in the study were two constructs that define science process skills, namely; basic science process skills and integrated science process skills. The former had five constructs and the later had four constructs each having two items. Under basic science process skills, observation had a mean of 1.59 , measuring had a mean of 1.44 , classifying had a mean of 1.23 , predicting had a mean of 1.40 and communicating had a mean of 1.30. Similarly, under integrated science process skills, controlling variables had a mean of 1.21 , hypothesizing had a mean of 1.15 , experimentation had a mean of 0.99 and data interpreting had a mean of 1.62. From all these, data interpreting, observation and measuring had the first three highest score $(1.62,1.59$ and 1.44$)$ respectively. And, the overall mean for science process skills is 1.33 , which on the scale used corresponded to disagree, implying that the level of students' knowledge of science process skills is poor.

\section{What is the level of students' attitudes towards physics?}

The dependent variable was divided into aspects namely; students' self-concept, students' anxiety, fear and students' aspiration. The items were scaled using the four-point Likert scale ranging from a minimum of 1 for the worst case scenario (strongly disagree) to a maximum of 4 , which is the best case scenario (Strongly agree). Table 3(a) for students' self-concept, eight items had the mean ranging from 3.42 to 3.91 , one item had a mean of 2.45 , one item had a mean of 2.54 , and an overall mean of 3.45 , which on the scale used corresponded to "strongly agree" and hence a very good overall self-rating of the respondents on students' selfconcept of learning. Table 3(b) also illustrates that for students' anxiety, four items had means ranging from 2.90 to 3.21 , one item had a mean of 3.51 , one item had a mean of 3.62, and an overall mean of about 3.21, which on the scale used corresponded to "agree" and hence a good overall self-rating of the respondents on students' anxiety. Table 3(c) indicates that for fear, the four items had means ranging from 3.67 to 3.90 and an overall mean of about 3.76, which on the scale used corresponded to "strongly agree" and hence a good overall self-rating of the respondents on students' fear. Table 3(d) indicates that for students' aspiration, one item had a mean of 2.21, one item had a mean of about 2.33, one item had a mean of 3.34 and an overall mean of about 2.29, which on the scale used corresponded to "disagree" and hence a poor overall self-rating of the respondents on students' aspiration. Therefore, the overall mean on Students' Attitudes Constructs is which on the used scale, corresponded to "strongly agree" implying a good level of students' attitudes towards physics.

\section{Is there a significant relationship between students' knowledge level of science process skills and their attitudes toward science?}

"To answer the third question of the study: "Is there any relationship existing between students' knowledge level of science process skills and their attitudes toward physics?" The association between students' knowledge level of science process skills and their attitudes toward physics was explored by calculating the correlation. A significant $(p=0.03)$ positive correlation of $(0.69)$ was found among these variables. This implies that there is a significant positive relationship between students' knowledge level of science process skills and their attitudes toward physics (Table 4).

\section{DISCUSSION}

\section{Science process skills}

The finding of the study shown in Table 1 revealed that the average of SPST was 1.33 which is poor. The results show that more students selected the correct options for items related to the Data interpreting, Observation, Measuring with first three higher means of 1.62, 1.59 and 1.44 respectively. They found the skill of data interpreting, observation and measuring easier than the other skills. While fewer of target students selected the correct option for items related to the skill of controlling variables and experimentation. The researcher believed that the secondary school students in Aliero metropolis have less experience in controlling variables and 
Table 1. Demographic characteristics of the respondents.

\begin{tabular}{|c|c|c|c|c|}
\hline \multirow{2}{*}{ Item } & \multirow{2}{*}{ Question } & \multirow{2}{*}{ Characteristic } & \multicolumn{2}{|c|}{ Distribution } \\
\hline & & & Frequency & Percentage \\
\hline \multirow{3}{*}{1} & \multirow{3}{*}{ Sex } & Male & 97 & 58.79 \\
\hline & & Female & 68 & 41.21 \\
\hline & & Total & 165 & 100 \\
\hline \multirow{4}{*}{2} & \multirow{4}{*}{ Age } & 18 & 91 & 55.15 \\
\hline & & $18+$ & 20 & 12.12 \\
\hline & & 17 & 54 & 32.73 \\
\hline & & Total & 165 & 100 \\
\hline \multirow{3}{*}{3} & \multirow{3}{*}{ Type of school } & Boarding & 125 & 75.76 \\
\hline & & Day school & 40 & 24.24 \\
\hline & & Total & 165 & 100 \\
\hline \multirow{3}{*}{4} & \multirow{3}{*}{ School } & Public School & 145 & 87.88 \\
\hline & & Private School & 20 & 12.12 \\
\hline & & Total & 165 & 100 \\
\hline
\end{tabular}

Table 2. Mean on science process skills constructs.

\begin{tabular}{lccc}
\hline Parameter & No. of items & Mean & Overall mean \\
\hline Basic skills & & & \\
Observation & 2 & 1.59 & \\
Measuring & 2 & 1.44 & 1.39 \\
Classifying & 2 & 1.23 & \\
Predicting & 2 & 1.40 & \\
Communicating & 2 & 1.30 & \\
Integrated skills & & & \\
Controlling variables & 2 & 1.21 & \\
Hypothesising & 2 & 1.15 & 1.24 \\
Experimentation & 2 & 0.99 & \\
Data Interpreting & 2 & 1.62 & \\
\hline
\end{tabular}

experimentation. This finding could be due to the traditional teaching method used by the teachers. The traditional methods cannot develop the integrated science process skills. The finding of this study supports the results of some previous studies, which showed that teacher and student's teachers did not reach the high level of acquisition of science process skills (Al-rabaani, 2014; Ozgelen, 2012). This finding is also in close agreement with the finding of Zeidan and Jayosi (2015) that the Palestinian secondary school students' had a moderate experience of science process skills.

\section{Attitudes toward science among Palestine secondary school students}

The finding of the study shown in Table 2 revealed that the average of SAQP was 3.44 implying a very good (very high) level of students' attitudes towards physics.
The finding of this study supports the results of Bang and Baker (2013) and that of Zeidan and Jayosi (2015) who found that the level of students' attitudes towards science is good, that students have high favorable attitudes towards physics oriented career courses. While the study revealed that students' self-concept of ability, anxiety and fear have high effect on students' attitudes towards physics, the effect of aspiration on students' attitudes towards physics is moderate. The male and female students had significantly higher positive attitudes towards science.

Relationship between science process skills and attitudes toward physics among secondary school students in Aliero

From Table 3, we found a significant positive relationship between science process skills and attitudes toward 
Table 3. Mean on students' attitudes constructs.

\begin{tabular}{lll}
\hline Parameter & Mean & Overall mean \\
\hline (a) Student' self-concept & 3.81 \\
I like practical work in physics because I can use equipment and scientific tools & 3.53 \\
It is exciting to learn about new things happening in science related to physics & 3.42 \\
I learn physics quickly & 3.72 \\
I like physics because it helps me to develop the skills of thinking & 3.64 \\
Physics excites questions, opinions and ideas & 3.72 \\
I like reading physics magazines and books & 3.80 \\
I would like to discuss physics topics with my classmates & 2.54 \\
In my physics class, I understand everything & 3.91 \\
Practical work in physics is exciting & 2.45 \\
I like Physics lessons more than most other subjects' lessons & \\
(b) Student's anxiety & \\
Physics lesson is boring & 3.51 \\
Practical work in physics is boring & 3.01 \\
I feel helpless when doing physics & 2.9 \\
Physics is not important for society & 2.98 \\
I find physics difficult & 3.62 \\
Practical work in physics is useless & 3.21 \\
& \\
(c) Fear & \\
I get scared when physics lesson is going on & 3.67 \\
I entertain fear whenever Physics teacher enters our class & 3.76 \\
I am afraid of my physics teacher & 3.71 \\
I am scared of calculation aspects of physics & 3.90 \\
(d) Aspiration & \\
I would like to study physics at university & \\
I would like to become a physics teacher & \\
I would like to do more physics activities outside of school & 3.21 \\
\hline
\end{tabular}

Table 4. Correlation between students' knowledge level of science process skills and their attitudes toward physics.

\begin{tabular}{llc}
\hline Correlations & & Students' attitudes towards physics \\
\hline \multirow{3}{*}{ Science process skills } & Pearson correlation & $.634^{\star}$ \\
& Sig. (2-tailed) & .002 \\
& $\mathrm{~N}$ & 165 \\
\hline
\end{tabular}

*. Correlation is significant at the 0.03 level (2-tailed).

physics among secondary school students in Aliero. The researcher believed that the positive attitudes toward makes students more interested in focusing on science process. In other words, when the students understand the science process skills, physics becomes more interesting to them, which increases the positive attitudes towards physics. This finding agrees with Downing and Filer's (1999) report that there was a significant relationship between science process skills among teachers and their attitudes toward science.

\section{CONCLUSION AND RECOMMENDATIONS}

The conclusion drawn from this work, based on the findings science process skills are the building block of critical thinking and enquiry in science which includes observing, classifying, inferring, predicting, communicating and measuring, these skills can be obtained by learners through science instruction activities. Also on the other hand, it was established that students' attitude highly affect teaching and learning of 
physics. However, the poor performance of students in physics was due to lack of innovation, encouragement and resourcefulness by the teachers, despite the teachers making the class more interactive and allowing students to ask question(s) whenever they have any doubt in them. Inability to solve physics questions correctly using the appropriate formula and not been able to see the relevance of physics to the society affects their learning. Consequently, the good ones among the students show that they have interest in physics lesson and thereby see no problem with the attitude of their teachers toward learning physics.

\section{RECOMMENDATIONS}

In this research, the researcher discovered some reasons or factors affecting science process skills and student's attitude toward learning physics. Therefore, necessary action should be taken towards modifying the factors in other to ensure positive attitude students' toward learning physics. The following recommendations were made based on the findings.

1. Students should be exposed to science process skills for the betterment of their future life and the society as well.

2. The level of students' attitudes toward physics is good but not enough. As such, positive attitudes of students should be improved so that they can be able to think, to reflect and to associate with ideas related to physics and science in general.

3. Prospective studies should be conducted based on a much wider sample and within the context to provide better understanding of the situation.

\section{REFERENCES}

Al-rabaani, A. (2014). The acquisition of science process skills by Omani's pre-service social studies' teachers. European Journal of Educational Studies, 6(1): 13-19.

Arnson, E., Wilson, D., and Akert, M. (1994). Social psychology. The heart and the mind. New York: Harper Collins.

Bang, E., and Baker, D. (2013). Gender differences in Korean high school students' science achievements and attitudes towards science in three different school settings. Mevlana I nternational Journal of Education, 3(2): 27-42.

Downing, J., and Filer, J. (1999). Science process skills and attitudes of pre-service elementary teachers. Journal of Elementary Science Education, 11(2): 57-64.

Gall, M. D., Gall, J. P., and Borg, W. R. (2003). Educational research, an introduction (7th Ed.). Boston: Allyn Bacon.

Ozgelen, S. (2012). Students science process skills within a cognitive domain framework. EURASIA Journal of Mathematics, Science and Technology Education, 8(4): 283-292.

Padilla, M. (1990). The science process skills. Paper 9004 in the series, science matters-to the science teacher, published by the National Association for research in science Teaching.
Thomas, R., Koballa, Jr., and Crawley, F. (1985). The influence of attitude on science teaching and learning. School Science and Mathematics, 85(3): 222-232.

Wheeler, L., Goodale, R., and Deese, J. (1974). General Psychology. Oxford, UK: Allyn and Bacon.

Zeidan, A. H., and Jayosi, M. R. (2015). Science process skills and attitudes toward science among Palestinian secondary school students. World Journal of Education, 5(1): 13-24.
Citation: Kamba, A. H., Giwa, A. A., Libata, I. A., and Wakkala, G. T. (2018). The relationship between science process skills and student attitude toward physics in senior secondary school in Aliero metropolis. African Educational Research Journal, 6(3): 107-113. 